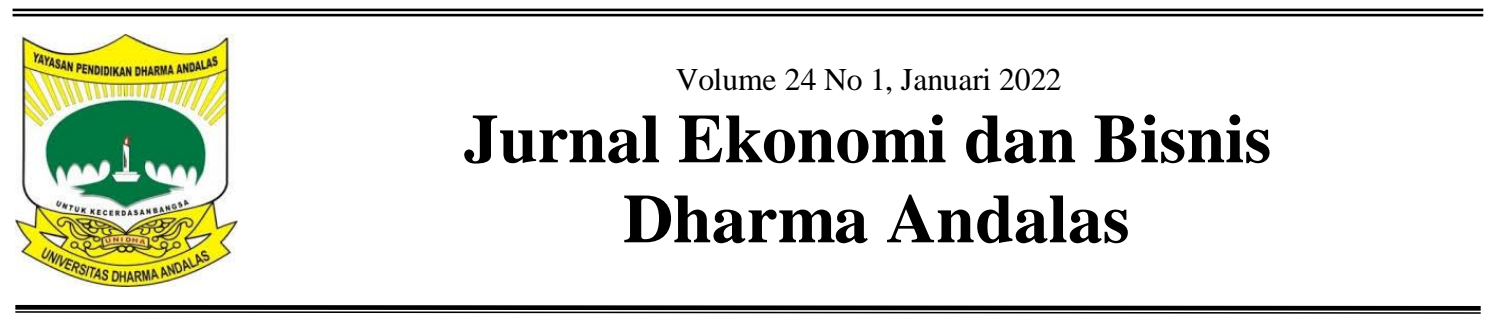

\title{
Analisis Sistem Penatausahaan Belanja Operasi Pada Badan Keuangan Daerah Provinsi Sumatera Barat
}

\author{
Dewi Sartika ${ }^{1}$, Fitrah Mulyani ${ }^{2}$, Andre Ilyas ${ }^{3}$ \\ Fakultas Ekonomi Ekonomi dan Bisnis, Universitas Dharma Andalas Padang ${ }^{\mathbf{1 . 2}}$ \\ Universitas Putra Indonesia "YPTK" Padang 3 \\ dsartika775@gmail.com ${ }^{1}$
}

\begin{abstract}
This study was conducted to analyze how the operating expenditure administration system at the regional financial agency of West Sumatra province was in accordance with the regulation of the Minister of Home Affairs number 77 of 2020. The research method carried out in this study wa a qualitative descriptive study, while the data collection techniques used library research, documentation and interviews. Based on the results of the study, it was found that regional financial agency of the province of West Sumatera has carried out and operating expenditure administration system in accordance with the applicable money regulations. As well as in submitting operating expenses using documents that have been determined, namely a letter of provision of funds, a letter of request for direct payment, a letter of order to pay, and a warrant for disbursmenet of funds.
\end{abstract}

Keywords: administration, operating expenditure, system

\begin{abstract}
ABSTRAK
Penelitian ini bertujuan untuk menganalisis bagaimana Sistem Administrasi Belanja Operasional pada Badan Keuangan Daerah Provinsi Sumatera Barat sesuai dengan Peraturan Menteri Dalam Negeri Nomor 77 Tahun 2020. Metode penelitian yang digunakan dalam penelitian ini adalah penelitian deskriptif kualitatif. Sedangkan teknik pengumpulan data menggunakan studi kepustakaan, dokumentasi dan wawancara. Berdasarkan hasil penelitian diketahui bahwa Badan Keuangan Daerah Provinsi Sumatera Barat telah menerapkan Sistem Administrasi Belanja Operasional sesuai dengan ketentuan yang berlaku. Demikian pula dalam pengajuan Belanja Operasional menggunakan dokumen yang telah ditentukan yaitu Surat Penyediaan Dana (SPD), Surat Permintaan Pembayaran Langsung (SPP-LS), Surat Perintah Membayar (SPM-LS), dan Surat Perintah untuk Penyaluran Dana (SP2D-LS).
\end{abstract}

Kata kunci : penatausahaan, belanja operasi, sistem

\section{PENDAHULUAN}

Pemerintah daerah saat ini dituntut untuk lebih mempersiapkan diri dan mampu mengantisipasi sedini mungkin segala kemungkinan yang akan terjadi dalam persaingan yang datang dari dalam negeri maupun luar negeri. Negara dengan wilayah yang luas membutuhkan sistem pemerintahan yang baik. Sistem ini sangat diperlukan setidaknya untuk dua hal, yaitu: pertama sebagai alat untuk melaksanakan pelayanan publik di berbagai daerah dan kedua sebagai motivasi bagi masyarakat lokal untuk berpartisipasi aktif dalam menentukan arah dan cara mengembangkan standar hidup mereka sendiri sejalan dengan 
peluang dan tantangan yang dihadapi dalam koridor kepentingan nasional.

Asas desentralisasi yang dianut oleh pemerintah Indonesia, yang memberikan kesempatan dan keleluasaan bagi daerah untuk mengurus daerah, diwujudkan dengan mengatur distribusi dan pemanfaatan sumber daya nasional serta perimbangan keuangan antara pemerintah pusat dan pemerintah daerah. Otonomi daerah juga dapat mempercepat pertumbuhan ekonomi dan pembangunan daerah, mengurangi disparitas antar daerah. Lahirnya Undang-Undang Nomor 23 Tahun 2014 tentang Pemerintahan Daerah yang menggantikan Undang-Undang Nomor 32 Tahun 2004 bukan hanya merupakan keinginan untuk melimpahkan kewenangan pembangunan dari pemerintah pusat kepada pemerintah daerah, tetapi yang lebih penting, pemerintah daerah dapat mengurus rumah tangganya sendiri secara profesional, memanfaatkan sumber daya yang dimiliki daerah dan mengelola keuangan daerah secara efisien dan efektif.

Penyelenggaraan otonomi daerah dilaksanakan dengan memberikan otonomi yang seluas-luasnya dan profesional kepada daerah, yang diwujudkan dengan mengatur, berbagi, dan memanfaatkan kemajuan teknologi dan ilmu pengetahuan sehingga tersedia data dan informasi yang dapat dianalisis dan dimanfaatkan secara cepat, tepat dan akurat. dengan aman. Salah satunya adalah pelaksanaan prosedur administrasi keuangan daerah. Penatausahaan keuangan berkepentingan untuk mengendalikan pelaksanaan anggaran dan belanja daerah, mengingat kewenangan yang telah diberikan melalui penetapan menjadi peraturan daerah dan pengesahannya oleh pejabat yang berwenang. Hal ini erat kaitannya dengan tugas pokok Bendahara yang berada di
Satuan Kerja Perangkat Daerah (SKPD) dan Satuan Kerja Pengelola Keuangan Daerah (SKPKD).

Penatausahaan keuangan daerah merupakan bagian yang tidak terpisahkan dari Pengelolaan Keuangan Daerah, baik menurut Peraturan Pemerintah Nomor 12 Tahun 2019 maupun berdasarkan Permendagri Nomor 77 Tahun 2020 tentang Pedoman Pengelolaan Keuangan Daerah. Uraian penyelenggaraan keuangan daerah meliputi: (a) asas umum penyelenggaraan keuangan daerah, (b) pelaksanaan administrasi keuangan daerah, (c) administrasi pendapatan, (d) administrasi pengeluaran.

Belanja daerah adalah semua arus kas yang keluar dari kas daerah. Penatausahaan pengeluaran dilakukan oleh bendahara pengeluaran SKPD dan bendahara pengeluaran SKPKD dengan menggunakan dokumen berupa Surat Permintaan Pembayaran (SPP), Surat Perintah Pembayaran (SPM), Surat Perintah Pencairan Dana (SP2D) baik UP, GU, maupun TU dan LS, Nota Pencairan Dana ( NPD), dan bukti pengeluaran lainnya yang sah. Pada akhir bulan, bendahara pengeluaran membuat SPJ untuk pengeluaran administrasi dan fungsional paling lambat tanggal 10 bulan berikutnya.

Pemerintah daerah pada setiap awal tahun anggaran menetapkan anggaran pendapatan dan belanja daerah (APBD) yang merupakan gambaran penerimaan dan pengeluaran daerah selama satu tahun anggaran dalam pengelolaan keuangan daerah. Selanjutnya pelaksanaan anggaran memerlukan prosedur yang sesuai dengan dokumen yang ditentukan, pertanggungjawaban sebagai bentuk pertanggungjawaban atas pengelolaan keuangan daerah untuk jangka waktu satu tahun. Belanja daerah atau pengeluaran pemerintah daerah dalam 
anggaran belanja daerah (APBD) merupakan salah satu faktor pendorong pertumbuhan ekonomi daerah.

Belanja daerah dalam rangka mendanai penyelenggaraan urusan pemerintahan yang menjadi kewenangan Provinsi atau Kabupaten/Kota yang terdiri atas urusan wajib, urusan pilihan, dan urusan yang penanganannya berada pada bagian atau bidang tertentu yang dapat dilaksanakan bersama antara pemerintah daerah. pemerintah dan pemerintah daerah atau antar pemerintah daerah diatur dengan ketentuan peraturan perundangundangan (Purnomo, 2009:40). Menurut Peraturan Pemerintah Republik Indonesia Nomor 12 Tahun 2019 tentang Pengelolaan Keuangan Daerah, belanja daerah terdiri dari empat jenis, yaitu: (a) Belanja Operasional, (b) Belanja Modal, (c) Belanja Tidak Diharapkan, dan (d) Transfer pengeluaran.

Belanja operasional adalah belanja anggaran untuk kegiatan sehari-hari pemerintah daerah yang memberikan manfaat jangka pendek. Belanja operasional terdiri dari belanja pegawai, belanja barang dan jasa, belanja bunga, belanja subsidi, belanja hibah, dan belanja bantuan sosial. Dalam akuntansi pemerintah Indonesia, beban usaha dapat diartikan sebagai pengeluaran kas, yang mengurangi ekuitas pada tahun anggaran dan tidak akan dapat diperoleh kembali oleh pemerintah. Di Pemerintah, Badan Keuangan Daerah, biaya operasional telah ditetapkan dalam Anggaran Pendapatan dan Belanja Daerah (APBD) untuk membiayai kegiatan dan proyek daerah selama satu tahun anggaran. Mencermati berjalannya sistem akuntansi pengeluaran operasional di suatu pemerintah daerah sangat penting untuk melihat transparansi atau dengan kata lain informasi keuangan yang terbuka dan jujur kepada publik. Masyarakat berhak mengetahui secara terbuka dan menyeluruh tanggung jawab pemerintah dalam mengelola sumber daya yang dipercayakan kepadanya dan kepatuhannya terhadap peraturan perundang-undangan serta mengetahui peruntukan uang yang tepat.

Berdasarkan hasil penelitian Wonggo, dkk (2017) dengan judul penelitian tentang analisis sistem administrasi belanja langsung pada Pemerintah Kabupaten Minahasa Selatan (Studi Kasus pada Dinas Sosial Tenaga Kerja dan Transmigrasi) dapat disimpulkan bahwa Dinas Sosial Tenaga Kerja dan Transmigrasi Kabupaten Minahasa Selatan selaku SKPD telah melaksanakan tata cara administrasi belanja langsung, dokumen yang digunakan untuk menyusun laporan pertanggungjawaban bendahara pengeluaran dan penyampaiannya sudah sesuai dengan ketentuan yang berlaku, hal ini berdasarkan Peraturan Menteri Dalam Negeri Nomor 21 Tahun 2011 dan sistem administrasi belanja LS sudah memadai. Meskipun masih terdapat kendala yang dihadapi oleh Dinas Sosial, Tenaga Kerja dan Transmigrasi Kabupaten Minahasa Selatan dalam melaksanakan Permendagri Nomor 21 Tahun 2011, seperti kesalahan pencatatan, prosedur yang tidak sesuai dengan peraturan.

Badan Keuangan Daerah Provinsi Sumatera Barat merupakan lembaga yang berkedudukan sebagai Satuan Kerja Pengelola Keuangan Daerah (SKPKD) dan Satuan Kerja Perangkat Daerah (SKPD). Badan Keuangan Daerah Provinsi Sumatera Barat memiliki peran yang sangat penting dalam mengelola pendapatan dan belanja daerah di Provinsi Sumatera Barat. Peran tersebut memiliki kontribusi yang signifikan dalam pencapaian pendapatan daerah yang tinggi, terutama untuk mengoptimalkan 
pendapatan daerah dan pengelolaan keuangan yang efektif dan efisien sehingga dapat dipertanggungjawabkan secara profesional.

Untuk meningkatkan akuntabilitas dan menghindari segala bentuk penyelewengan, penggelapan, penggelapan dan pemborosan aset negara terhadap uang tunai, maka sistem dan prosedur yang telah ditetapkan sebelumnya oleh pemerintah dan tertuang dalam undang-undang dan peraturan terkait seperti Peraturan Menteri Dalam Negeri No. 2020 menjelaskan tentang Pedoman Teknis Pengelolaan Keuangan Daerah dan sebagai pedoman dasar dalam pengelolaan keuangan baik penerimaan maupun pengeluaran kas.

Peraturan Menteri Dalam Negeri Nomor 77 Tahun 2020 ini menggantikan Peraturan Menteri Dalam Negeri Nomor 21 Tahun 2011 tentang Pedoman Teknis Pengelolaan Keuangan Daerah. Peraturan ini disusun untuk menyempurnakan pengaturan Pengelolaan Keuangan Daerah yang sebelumnya diatur dalam Peraturan Pemerintah Nomor 21 Tahun 2011 tentang Pengelolaan Keuangan Daerah. Perbaikan ini dilakukan untuk menjaga tiga pilar pengelolaan keuangan daerah yang baik, yaitu transparansi, akuntabilitas, dan partisipatif.

Badan Keuangan Daerah Provinsi Sumatera Barat telah menerapkan Peraturan Menteri Dalam Negeri Nomor 77 Tahun 2020 tentang Pedoman Teknis Pengelolaan Keuangan Daerah sejak tahun 2020 hingga sekarang. Dari hasil wawancara dengan Kepala Bagian Perbendaharaan Pengeluaran pada Badan Keuangan Daerah Provinsi Sumatera Barat mengatakan bahwa dalam melaksanakan sistem administrasi belanja operasional harus mengacu pada peraturan yang telah diatur dalam Permendagri Nomor 77 Tahun 2020.
Namun sejauh mana penatausahaan belanja operasional pada Badan Keuangan Daerah Provinsi Sumatera Barat dapat dilaksanakan sesuai dengan ketentuan yang telah ditetapkan, mengingat peraturan perundangundangan tersebut baru digunakan pada tahun 2020.

\section{METODE PENELITIAN}

Jenis dan Sumber Data

Jenis data yang digunakan adalah data kualitatif yaitu data yang tidak dapat diukur dalam skala numerik, metode penyajian datanya adalah deskriptif (Kuncoro, 2014: 145). Sumber data penelitian ini adalah data sekunder dan data primer. Data sekunder berupa gambaran umum, visi, misi, struktur organisasi, uraian tugas pokok, dan fungsi serta dokumen, prosedur, dan informasi tentang Sistem Administrasi Belanja Operasional pada Badan Keuangan Daerah Provinsi Sumatera Barat. Data primer diperoleh dengan cara mewawancarai narasumber yang dianggap mampu memberikan informasi yang akurat tentang topik yang diteliti.

Metode Pengumpulan Data

Dalam penelitian ini penulis menggunakan beberapa metode yang digunakan sebagai sarana untuk mencari informasi yang berkaitan dengan materi pelajaran

Metode pertama adalah studi literatur, metode ini dapat diartikan sebagai teknik pengumpulan data dengan melakukan studi tinjauan terhadap buku, literatur, catatan, dan laporan yang ada hubungannya dengan masalah yang sedang dipecahkan (M. Nazir, 1998:111). Dalam metode ini, penulis melakukan studi kepustakaan dengan mempelajari dan memahami buku-buku dari berbagai sumber perpustakaan beserta jurnaljurnal terkait yang terkait dengan permasalahan dalam pembahasan ini. Dan membandingkan temuan di lapangan 
dengan Permendagri Nomor 77 Tahun 2020 .

Metode kedua adalah dokumentasi, metode ini merupakan suatu cara untuk memperoleh informasi dan data berupa buku, arsip, dokumen, angka tertulis dan gambar berupa laporan dan informasi yang dapat menunjang penelitian (Sugiyono, 2015:329). Dalam metode ini, penulis melakukan dokumentasi melalui pengambilan gambar dan dokumen terkait seperti Surat Penyediaan Dana (SPD), SPP-LS, SPMLS, dan SP2D.

Metode ketiga adalah wawancara, merupakan suatu metode pengumpulan data dengan menanyakan sesuatu kepada seseorang yang menjadi informan atau responden (Afifuddin, 2009:131). Dalam metode wawancara ini penulis mendapatkan informasi secara langsung dengan mewawancarai Bapak Andri Yovianda, SE, MM selaku Kepala Bendahara Pengeluaran pada Badan Keuangan Daerah Provinsi Sumatera Barat.

Metode Analisis Data

Metode deskriptif yang digunakan dalam penelitian ini adalah metode pembahasan masalah yang bersifat deskriptif, mendeskripsikan membandingkan suatu data atau situasi dan menggambarkan serta menjelaskan suatu situasi sedemikian rupa sehingga dapat ditarik kesimpulan. Penulis mengidentifikasi prosedur administrasi yang berlangsung di SKPD, serta dokumen yang digunakan sehubungan dengan komponen belanja operasional di Badan Keuangan Daerah Provinsi Sumatera Barat mulai dari penerbitan SPD-LS, Pengajuan SPP- LS, Penerbitan SPM-LS, hingga penerbitan SP2D-LS. Setelah mengidentifikasi prosedur administrasi yang berlangsung di SKPD, penulis akan menganalisis kesesuaian Sistem Administrasi Belanja Operasional pada Badan Keuangan Daerah Provinsi
Sumatera Barat yang telah dilaksanakan oleh Badan Keuangan Daerah Provinsi Sumatera Barat dengan Menteri Dalam Negeri. Peraturan Menteri Nomor 77 Tahun 2020 tentang Pedoman Teknis Pengelolaan Keuangan Daerah.

\section{HASIL DAN PEMBAHASAN \\ Sistem Penatausahaan Belanja Operasi berdasarkan Permendagri Nomor 77 Tahun 2020}

Sistem penyelenggaraan SKPD merupakan rangkaian komponen dalam pencatatan pendapatan dan belanja daerah secara tertib, sistematis dan kronologis selama satu tahun anggaran. Penatausahaan pada tingkat satuan kerja perangkat daerah (SKPD) dilaksanakan oleh Pengguna Anggaran/Kuasa Pengguna Anggaran, Pejabat Penatausahaan Keuangan Satuan Kerja Perangkat Daerah (PPK-SKPD), Pejabat Pelaksana Teknis (PPTK) dan Bendahara Pengeluaran serta pembantu bendahara pengeluaran apabila diperlukan.

Dalam sistem administrasi belanja operasional pada Badan Keuangan Daerah Provinsi Sumatera Barat dilakukan sesuai dengan mekanisme Permendagri Nomor 77 Tahun 2020 dalam menjalankan tugas dan fungsinya masing-masing. Sistem administrasi belanja operasional yang telah diatur dalam Permendagri Nomor 77 Tahun 2020 adalah sebagai berikut:

\section{Penerbitan Surat Penyediaan Dana (SPD) \\ SPD adalah surat kuasa yang} diterbitkan oleh BUD/BUD yang menyatakan tersedianya dana di Kas Umum Daerah untuk melaksanakan kegiatan sebagai dasar penerbitan SPP. SPD disusun oleh Kuasa BUD dan disampaikan kepada PPKD untuk ditandatangani. Berdasarkan Pasal 135 Peraturan Pemerintah Nomor 12 Tahun 2019 menegaskan bahwa dalam rangka 
kepengurusan, PPKD menerbitkan SPD dengan memperhatikan:

a. Anggaran Kas Pemerintah Daerah

b. Ketersediaan dana di Kas Umum Daerah

c. Penjadwalan pembayaran pelaksanaan anggaran yang tercantum dalam DPA SKPD.

Terkait hal tersebut di atas, Peraturan Menteri ini mengatur beberapa ketentuan sebagai berikut :

a. SPD sebagai dasar permintaan pembayaran sesuai kebutuhan SKPD atau unit SKPD setiap periodik.

b. Untuk pembayaran pengeluaran kebutuhan tanggap darurat bencana, konflik sosial, dan atau/ kejadian luar biasa, PPKD selaku BUD dapat melakukan perubahan SPD atau dokumen yang dipersamakan yang bersumber dari anggaran yang ditetapkan pada DPA-SKPD yang menyelenggarakan fungsi SKPKD.

c. PPKD selaku BUD dapat melakukan perubahan SPD apabila terdapat kondisi sebagai berikut :

1) Ketersediaan dana pada RKUD yang tidak sesuai perkiraan penerimaan dalam anggaran kas.

2) Perubahan jadwal pelaksanaan sub kegiatan akibat keadaan darurat termasuk keperluan mendesak.

3) Perubahan SPD menjadi dasar permintaan pembayaran berikutnya.

d. Penyusunan dan penerbitan SPD memuat informasi, aliran data, serta penggunaan dan penyajian dokumen yang dilakukan secara elektronik.

Langkah-langkah dalam Penerbitan Surat Penyediaan Dana (SPD)

Bendahara pengeluaran terlibat dalam pembuatan dan penerbitan permohonan penerbitan SPD yang dilampiri dengan bukti dan jumlah permintaan anggaran belanja yang diperiksa oleh Pejabat Pelaksana Teknis (PPTK) untuk menyiapkan bukti pendukung berupa surat pernyataan. nota pengeluaran anggaran belanja untuk pelaksanaan kegiatan dan penandatanganan surat permohonan beserta lampirannya. Setelah ditandatangani oleh PPTK kemudian dokumen diserahkan kepada Pengguna Anggaran untuk diperiksa kembali dan ditandatangani surat permohonan penerbitan SPD beserta lampirannya, bendahara pengeluaran mengajukan permohonan penerbitan SPD yang ditunjukkan kepada Bendahara Umum Daerah (BUD) sebagai syarat diterbitkannya SPD. Surat permohonan disampaikan dengan melampirkan lampiran DPA-SKPD yang memuat rekening anggaran operasional. Setelah itu surat permohonan penerbitan SPD ditandatangani oleh Bendahara Pengeluaran dan Ketua Pelaksana selaku pengguna anggaran yang selanjutnya akan menerbitkan SPD adalah PPKD. Kebijakan Penerbitan SPD adalah:

a. SPD disesuaikan dengan kebutuhan SKPD periode tertentu yang ditetapkan dalam Anggaran Kas Pemerintah daerah.

b. BUD dapat menerbitkan SPD untuk pengeluaran kebutuhan tanggap darurat bencana, konflik sosial bersumber dari DPA-SKPD dari perubahan SPD periode berjalan.

c. SPD dapat diubah jika ketersediaan dana tidak sesuai dengan perkiraan penerimaan kas perubahan karena adanya pengeluaran kebutuhan darurat, dan perubahan atas dasar permintaan pembayaran berikutnya.

\section{Pengajuan Surat Permintaan Pembayaran (SPP-LS)}

Berdasarkan SPD atau dokumen lain yang dipersamakan dengan SPD, maka langkah selanjutnya bendahara pengeluaran adalah menyampaikan Surat Permintaan Pembayaran (SPP) kepada 
pengguna anggaran/kuasa pengguna anggaran melalui Unit PPK-SKPD/PPKSKPD. Permintaan pembayaran dilakukan oleh Bendahara Pengeluaran atau Pembantu Bendahara Pengeluaran yang merupakan proses awal pembayaran oleh Pemerintah Daerah kepada Pihak Terkait serta proses penetapan rekening pengeluaran. Proses permintaan pembayaran berisi informasi, aliran data, serta penggunaan dan penyajian dokumen secara elektronik. SPP yang dapat diajukan oleh Bendahara Pengeluaran terdiri dari:

a.SPP Uang Persedian (SPP-UP)

b. SPP Ganti Uang (SPP-GU)

c.SPP Tambah Uang (SPP-TU)

d. SPP Langsung (SPP-LS)

\begin{tabular}{lc}
\multicolumn{2}{c}{ Penerbitan dan pengajuan } \\
dokumen SPP-LS dilakukan oleh \\
$\begin{array}{l}\text { Bendahara } \\
\text { pembayaran : }\end{array}$
\end{tabular}

a. Gaji dan tunjangan

b. Kepada pihak ketiga atas pengadaan barang dan jasa

c. Kepada pihak ketiga lainnya sesuai dengan ketentuan peraturan perundang-undangan

Pengajuan SPP-LS disertai dengan berbagai kelengkapan sesuai dengan jenis pengajuannya berdasarkan ketentuan peraturan perundangundangan. Pengajuan Permintaan Pembayaran LS ini didokumentasikan dalam SPP-LS yang terdiri atas :

a. Ringkasan SPP-LS

b. Rincian belanja yang diajukan pembayarannya sampai dengan sub rincian objek

c. Pihak ketiga berkewajiban untuk menyampaikan kode e-billing untuk pembayaran atau penyetoran pajak secara eloktronik kepada PPTK.

Langkah-langkah dalam Pengajuan Surat Permintaan Pembayaran LS Gaji dan Tunjangan
Adapun langkah-langkah dalam pengajuan permintaan pembayaran LS Gaji dan Tunjangan adalah sebagai berikut :

a. PPTK menyiapkan rekapitulasi daftar gaji dan tunjangan sebagai dokumen pengajuan permintaan pembayaran LS Gaji dan Tunjangan.

b. Rekapitulasi daftar gaji dan tunjangan harus dilengkapi dengan :

1) Daftar perubahan data pegawai yang ditandatangani oleh pejabat sesuai kewenangan.

2) Salinan dokumen pendukung perubahan data pegawai yang telah dilegalisasi oleh pejabat yang berwenang meliputi :

a) Gaji induk

b) Gaji susulan

c) Kekurangan gaji

d) Gaji terusan

e) SK CPNS

f) SK PNS

g) SK kenaikan pangkat

h) SK jabatan

i) Kenaikan gaji berkala

j) Surat pernyataan pelantikan

k) Surat pernyataan melaksanakan tugas

1) Daftar keluarga

m) Foto kopi surat nikah

n) Foto kopi akte kelahiran

o) Surat keterangan pemberhentian pembayaran (SKPP) gaji

p) Surat keterangan masih sekolah/kuliah

q) Surat pindah

r)Surat kematian

c. Kelengkapan dokuemen di atas disesuaikan dengan peruntukannya. Selanjutnya Bendahara pengeluaran memverifikasi rencana belanja gaji dan tunjangan berdasarkan rekapitulasi daftar gaji dan tunjangan dan dokumen pendukung dengan langkah antara lain sebagai berikut : 
1) Meneliti dokumen DPA untuk memastikan bahwa belanja gaji dan tunjangan yang akan diajukan tidak melebihi sisa anggaran.

2) Meneliti dokumen SPD terkait untuk memastikan dana untuk belanja gaji dan tunjangan yang akan diajukan telah disediakan.

3) Meneliti validitas perhitungan dokumen daftar gaji.

4) Setelah diverifikasi, Bendahara Pengeluaran menyiapkan pengajuan permintaan pembayaran LS Gaji dan Tunjangan yang didokumentasikan dalam SPP-LS Gaji dan Tunjangan kepada PA (Pengguna Anggaran) melalui PPK-SKPD/PPK-Unit SKPD berdasarkan SPD.

Langkah-langkah dalam Pengajuan Surat Permintaan pembayaran LS

Barang dan Jasa

Adapun langkah-langkah dalam pengajuan permintaan pembayaran LS Barang dan Jasa antara lain adalah sebagai berikut :

a. Bendahara Pengeluaran atau Bendahara Pengeluaran Pembantu menyiapkan SPP-LS Pengadaan Barang dan Jasa dengan mengacu kepada berita acara dan dokumen pengadaan. Dokumen pengadaan yang dimaksud antara lain :

1) Dokumen kontrak

2) Berita acara pemeriksaan

3) Berita acara kemajuan pekerjaan

4) Berita acara penyelesaian pekerjaan

5) Berita acara serah terima barang dan jasa

6) Berita acara pembayaran

7) Surat jaminan bank

8) Surat referensi/keterangan bank

9) Jaminan pembayaran dari bank yang sama dengan bank RKUD
10) Surat pernyataan kesanggupan dari pihak lain/rekanan untuk menyelesaikan pekerjaan seratus persen sampai dengan berakhir masa kontrak.

11) Dokumen lain yang dipersyaratkan untuk kontrakkontrak yang dananya sebagian atau seluruhnya bersumber dari penerusan pinjaman/hibah luar negeri. Untuk kelengkapan dokumen pengadaan di atas disesuaikan dengan kebutuhan berdasarkan jenis atau sifat pengadaan barang dan jasa yang dilakukan.

b. Setelah itu Bendahara Pengeluaran atau Bendahara Pengeluaran Pembantu memverifikasi rencana belanja pengadaan barang dan jasa dengan langkah antara lain:

1) Meneliti dokumen SPD terkait untuk memastikan dana untuk belanja pengadaan barang dan jasa yang akan diajukan telah disediakan.

2) Meneliti dokumen DPA untuk memastikan bahwa belanja pengadaan barang dan jasa yang akan diajukan tidak melebihi sisa anggaran.

3) Meneliti kelengkapan dan validitas perhitungan atas tagihan pihak ketiga, Berita Acara Serah terima (BAST), dan dokumen pengadaan barang dan jasa.

c. Setelah diverifikasi, Bendahara Pengeluaran menyiapkan pengajuan permintaan pembayaran LS Pengadaan Barang dan Jasa yang didokumentasikan dalam SPP-LS Pengadaan Barang dan Jasa kepada PA/KPA melalui PPK-SKPD/PPKUnit SKPD.

d. Bendahara Pengeluaran mengajukan pesetujuan permintaan pembayaran LS Pengadaan Barang dan Jasa 
tersebut kepada PA/KPA melalui PPK-SKPD/PPK-Unit SKPD.

Langkah-langkah dalam Pengajuan Permintaan Pembayaran LS kepada Pihak Ketiga Lainnya

Adapun langkah-langkah dalam pengajuan permintaan pembayaran LS kepada Pihak Ketiga Lainnya adalah sebagai berikut :

a. Bendahara Pengeluaran atau Bendahara Pengeluaran Pembantu menyiapkan SPP-LS kepada pihak ketiga lainnya dan dokumen pendukung lainnya.

b. Besaran pengajuan SPP-LS kepada pihak ketiga lainnya sesuia dengan ketentuan peraturan perundangundangan, dihitung berdasarkan keputusan kepala daerah dan atau/dokumen pendukung lainnya yang telah diverifikasi oleh bendahara pengeluaran.

c. Bendahara Pengeluaan atau Bendahara Pengeluaran Pembantu memverifikasi rencana pembayaran kepada pihak ketiga lainnya sesuai dengan ketentuan peraturan perundang-undangan dengan langkah antara lain :

1) Meneliti dokumen DPA untuk memastikan bahwa pembayaran kepada Pihak Ketiga lainnya sesuai dengan ketentuan perundang-undangan yang akan diajukan tidak melebihi sisa anggaran.

2) Meneliti dokumen SPD terkait untuk memastikan dana untuk pembayaran kepada Pihak Ketiga lainnya sesuai dengan ketentuan peraturan perundang-undangan yang akan diajukan telah disediakan.

3) Meneliti kelengkapan dan validitas perhitungan berdasarkan keputusan Kepala Daerah dan/atau dokumen pendukung lainnya.

d. Setelah diverifikasi, Bendahara Pengeluaran atau Bendahara Pengeluaran Pembantu mengajukan Permintaan LS kepada Pihak Ketiga lainnya yang didokumentasikan dalam SPP-LS kepada Pihak Ketiga lainnya.

e. Bendahara Pengeluaran atau Bendahara Pengeluaran Pembantu mengajukan persetujuan permintaan pembayran LS pihak ketiga lainnya tersebut kepada PA/KPA melalui PPK-SKPD/PPK-Unit SKPD.

\section{Penerbitan Surat Perintah Membayar (SPM-LS)}

Perintah Membayar adalah kewenangan yang dimiliki oleh Pengguna Anggaran untuk belanja yang telah dianggarkan dalam DPA SKPD. Perintah membayar didahului dengan proses pengungkit belanja oleh PPK SKPD yang segera setelah pengakuan belanja tersebut. Proses perintah membayar seluruh informasi, aliran data, serta penggunaan dan penyajian dokumen yang dilakukan secara elektronik. Perintah pembayaran yang diajukan oleh Pengguna Anggaran kepada SPM yang dibuat oleh PPK-SKPD/PPK-Unit SKPD sebelumnya setelah melakukan penyempurnaan dan keabsahan pengajuan pembayaran. Adapun jenis SPM terdiri atas :

a) SPM Uang Persediaan (SPM-UP)

b) SPM Ganti Uang (SPM-GU)

c) SPM Tambah Uang (SPM-TU)

d) SPM Langsung Gaji dan Tunjangan (SPM-LS)

e) SPM Langsung Pengadaan Barang dan Jasa (SPM-LS)

f) SPM Langsung Pihak ketiga lainnya (SPM-LS)

Langkah-langkah dalam Penerbitan Surat Perintah Membayar (SPM-LS)

Adapun langkah-langkah dalan Penerbitan Surat Perintah Membayar 
(SPM-LS) antars lain adalah sebagai berikut :

a. Berdasarkan pengajuan SPP-LS oleh Bnedahara Pengeluaran atau Bendahara Pengeluaran Pembantu yang dilengkapi dengan dokumendokumen pendukungnya, PPKSKPD/PPK-Unit SKPD melakukan verifikasi dengan langkah berupa :

1) Meneliti dokumen DPA untuk memastikan bahwa belanja terkait tidak melebihi sisa anggaran.

2) Meneliti dokumen SPD untuk memastikan bahwa danan untuk belanja terkait telah disediakan.

3) Meneliti kelengkapan dokumen sesuai dengan jenis pengajuannya berdasarkan ketentuan perundang-undangan sebagaimana yang tersimpan dalam dokumentasi di sistem.

4) Meneliti keabsahan dokumendokumen pendukung.

5) Meneliti kesesuaian jumlah perhitungan pengajuan LS dengan dokumen pendukungnya.

b. Apabila terdapat ketidaklengkapan atau ketidaksesuaian maka PPKSKPD atau PPK-Unit SKPD meminta perbaikan atau penyempurnaan kepada Bendahara Pengeluaran atau Bendahara Pengeluaran Pembantu paling lambat 1 (satu) hari sejak diterimanya SPP-LS.

c. Apabila dalam verifikasi sudah dinyatakan lengkap dan sah, PPKSKPD/PPK-Unit SKPD menyiapkan pengajuan SPM-LS yang telah didokumentasikan dalam draft SPMLS untuk ditandatangani oleh PA/KPA.

d. Pengguna Anggaran/Kuasa Pengguna Anggaran memandatangani dan menerbitkan SPM-LS paling lama 2 (dua) hari sejak proses verifikasi dinyatakan lengkap dan sah untuk disampaikan kepada Kuasa BUD, dilengkapi dengan :

1) Surat Pernyataan tanggung jawab mutlak PA/KPA.

2) Surat pernyataan verifikasi PPK-SKPD/PPK-Unit SKPD yang dilampiri checklist kelengkapan dokumen.

e. Penerbitan SPM-LS dapat dilakukan dengan menerapkan ETP yang dicetak dan dikirim secara online dalam bentuk file kepada Kuasa BUD.

\section{Penerbitan Surat Perintah Pencairan Dana (SP2D-LS)}

Surat Perintah Pencairan Dana dibuat oleh BUD untuk mengeluarkan sejumlah uang dari RKUD berdasarkan SPM yang diterima dari PA/KPA. Surat perintah pembayaran kepada pihak terkait ditujukan kepada bank operasional mitra kerja untuk mencairkan dana di RKUD dengan tujuan pihak-pihak terkait sesuai dengan jenis SPM dan SPP yang diajukan. Proses penerbitan surat perintah menerbitkan dana untuk mengakses informasi, alira data, serta penggunaan dan penyajian dokumen yang dilakukan secara elektronik.

Penerbitan SP2D oleh Kuasa BUD dilakukan untuk membayar belanja yang menjadi beban APBD melalui mekanisme giralisasi. mekanisme giralisasi adalah mekanisme pembayaran non tunai melalui perbankan dengan cara melakukan pembayaran kepada pihak yang berhak menerima melalui rekening dari kas daerah kepada rekening yang berhak menerima. Kuasa BUD menerbitkan SP2D sesuai dengan SPM yang diajukan oleh pengguna anggaran yaitu SP2D untuk uang persediaan (SP2D-UP), SP2D untuk mekanisme tambah uang (SP2D-TU), dan SP2D untuk mekanisme pembayaran langsung (SP2D-LS), serta SP2D untuk mengganti uang (SP2D-GU) diterbitkan kepada rekening bendahara pengeluaran. 
Sedangkan SP2D-LS diterbitkan kepada pihak ketiga.

Langkah-langkah dalam Penerbitan Surat Perintah Pencairan Dana

(SP2D-LS)

Adapun langkah-langkah dalam penerbitan surat perintah pencairan dana (SP2D-LS) antara lain adalah sebagai berikut :

a. Kuasa BUD menerbitkan SP2D-LS yang diterima dari Pengguna Anggaran yang ditujukan kepada bank operasional mitra kerjanya.

b. Penerbitan SP2D-LS dilakukan paling lama 2 (dua) hari sejak SPM diterima.

c. Dalam rangka penerbitan SP2D-LS, Kuasa BUD berkewajiban untuk :

1) Meneliti kelengkapan SPM yang diterbitkan oleh PA/KPA berupa surat pernyataan tanggung jawab PA/KPA.

2) Menguji kebenaran perhitungan tagihan atas beban APBD yang tercantum dalam perintah pembayaran.

3) Menguji ketersediaan dana kegiatan yang bersangkutan.

4) Memerintahkan pencairan dana sebagai dasar pengeluaran daerah.

d. Kuasa BUD tidak menerbitkan SP2DLS yang diajukan PA/KPA apabila :

1) Tidak dilengkapi surat pernyataan tanggung jawab PA/KPA.

2)Pengeluaran tersebut melampaui pagu.

e. Kuasa BUD mengembalikan dokumen SPM-LS dalam hal SP2D-LS tidak diterbitkan paling lambat 1 hari terhitung sejak diterimanya SPM-LS.

f. Dalam hal proses verifikasi dinyatakan lengkap, Kuasa BUD menerbitkan Perintah Pencairan Dana yang didokumentasikan dalam SP2DLS.

\section{Pihak-pihak yang terkait dalam Belanja Operasi}

Berdasarkan Permendagri Nomor 77 Tahun 2020 adapun pihak-pihak yang terkait dalam belanja operasi adalah sebagai berikut :

a) Kuasa Bendahara Umum Daerah (BUD)

Kuasa Bendahara Umum Daerah (BUD) merupakan pejabat yang diberi kuasa untuk melaksanakan tugas sebagai bendahara umum daerah.

b) PPKD

PPKD atau Pejabat Pengelola Keuangan Daerah adalah Kepala Satuan Kerja Pengelola Keuangan Daerah (SKPKD) yang mempunyai tugas melaksanakan pengelolaan APBD dan bertindak sebagai bendahara umum daerah.

c) Pengguna Anggaran

PA atau Pengguna Anggaran adalah pejabat pemegang kewenangan

penggunaan anggaran untuk melaksanakan tugas dan fungsi SKPD yang dipimpinnya.

d) PPK-SKPD

PPK-SKPD atau Pejabat

Penatausahaan Keuangan Satuan

Kerja Perangkat Daerah adalah pejabat yang melaksanakan fungsi tata usaha keuangan pada SKPD sebagai pejabat penatausahaan keuangan SKPD.

e) PPTK

PPTK atau Pejabat Pelaksana Teknis Kegiatan adalah Pejabat pada unit SKPD yang melaksanakan satu atau beberapa kegiatan dari suatu program sesuai dengan bidang tugasnya.

f) Bendahara Pengeluaran

Bendahara Pengeluaran adalah pejabat yang ditunjuk menerima, menyimpan, membayarkan, menatausahakan, dan 
mempertanggungjawabkan uang untuk keperluan Belanja Daerah dalam rangka pelaksanaan ABPD pada SKPD.

\section{Analisis Kesesuaian Sistem Penatausahaan Belanja Operasi pada Badan Keuangan Daerah Provinsi Sumatera Barat berdasarkan 2020 Permendagri Nomor 77 Tahun}

Berikut adalah analisis kesesuaian antara Sistem Penatausahaan Belanja Operasi pada Badan Keuangan Daerah Provinsi Sumatera Barat berdasarkan Peraturan Pemerintah Menteri Dalam Negeri Nomor 77 Tahun 2020.

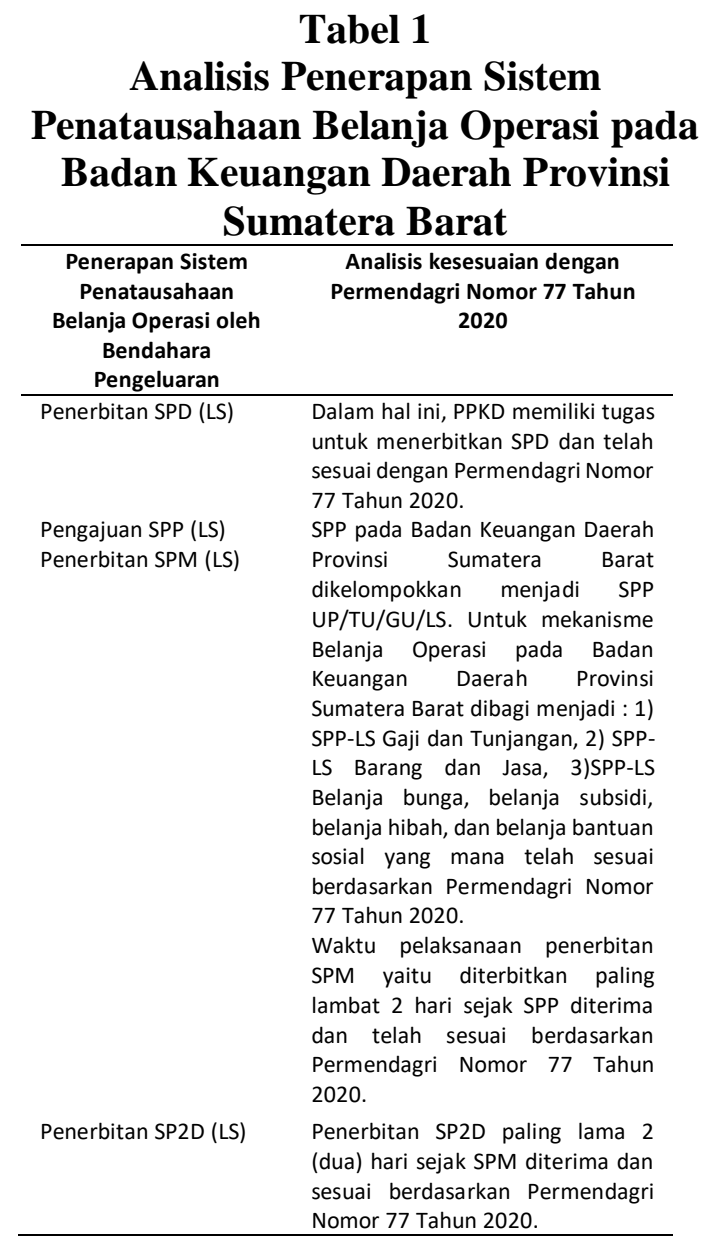

Sumber : Hasil wawancara dengan Kepala Bidang Bendahara Pengeluaran Badan Keuangan Daerah Provinsi Sumatera Barat.

Berdasarkan hasil wawancara secara langsung dengan Bapak Andri Yovianda, SE, MM selaku Kepala pada bagian bendahara pengeluaran Badan Keuangan Daerah Provinsi Sumatera Barat. Pertanyaan yang penulis ajukan adalah pertanyaan berdasarkan sistem penatausahaan belanja operasi pada Badan Keuangan Daerah Provinsi Sumatera Barat yang telah ditetapkan dalam peraturan yang saat ini berlaku yaitu Peraturan Menteri Dalam Negeri Nomor 77 Tahun 2020. Kemudian narasumber (bendahara pengeluaran) menjawab sesuai dengan praktik yang sesungguhnya dilakukan, sehingga penulis bisa menganalisis bagaimana sistem yang telah diterapkan pada Badan Keuangan Daerah Provinsi Sumatera Barat. Setelah penulis melakukan wawancara terhadap subyek penelitian, adapun hasilnya adalah sebagai berikut :

\section{a) Penerbitan Surat Penyediaan Dana (SPD)}

Dari hasil penelitian yang diperoleh, sistem penerbitan Surat Penyediaan Dana pada Badan Keuangan Daerah Provinsi Sumatera Barat adalah sebagai berikut :

1) Kuasa BUD menyiapkan rancangan SPD setelah menerima DPA-SKPD dan anggaran kas SKPD. Kuasa BUD menyiapkan rancangan SPD berdasarkan DPA-SKPD dan anggaran kas pemerintah daerah. Rancangan SPD yang dibuat itu akan berisi jumlah penyediaan dana yang dibutuhkan. Dokumen DPASKPD dan dokumen Anggaran Kas diteliti kelengkapannya apakah sudah lengkap atau belum. Jika sudah lengkap maka diterbitkan dokumen Rancangan SPD tersebut dan diserahkan kepada Pejabat Penatausahaan Keuangan Daerah (PPKD).

2) Dokumen rancangan SPD diperiksa kembali apakah sudah sesuai, jika sudah sesuai maka 
diotorisasi oleh PPKD dan menjadi dokumen SPD.

3) Setelah PPKD mengotorisasi rancangan SPD, PPKD menyerahkan SPD kepada pengguna anggaran/kuasa pengguna anggaran.

4) Pengguna Anggaran mengajukan dokumen SPD dan diserahkan kepada Bendahara Pengeluaran dan PPK-SKPD.

5) Selanjtunya Bendahara Pengeluaran menerima SPD dan memeriksa dokumen SPD apakah sudah sesuai jika sudah sesuai maka diterbitkan SPP-LS (Surat Permintaan Pembayaran Langsung) dan dokumendokumen lainnya kemudian diserahkan kepada PPK-SKPD.

\section{Adapun pihak-pihak yang terkait} dalam proses penerbitan Surat Penyediaan Dana antara lain adalah :

1. Kuasa BUD atau Kuasa Bendahara Umum Daerah

Dalam kegiatan ini Kuasa BUD mempunyai tugas sebagai berikut :

a) Menganalisa DPA SKPD yang ada di database.

b) Menganalisa anggaran kas pemerintah khususnya data per SKPD.

c) Menyiapkan draft Surat Penyediaan Dana (SPD).

d) Mendistribusikan Surat Penyediaan Dana (SPD) kepada para pengguna anggaran.

2. PPKD atau Pejabat Pengelola Keuangan Daerah selaku BUD

Dalam kegiatan ini PPKD mempunyai tugas sebagai berikut :

a) Meneliti dokumen Surat Penyediaan Dana (SPD) yang diajukan oleh Kuasa Bendahara Umum Daerah (BUD).

b) Melakukan otorisasi Surat Penyediaan Dana (SPD).

3. PA atau Pengguna Anggaran
Dalam kegiatan ini Pengguna Anggaran memiliki tugas sebagai berikut :

a) Memberikan keterangan yang diperlukan oleh Kuasa BUD.

b) Mengarsipkan SPD yang diterima.

b) Pengajuan Surat Permintaan Pembayaran Langsung (SPP-LS)

Berdasarkan Surat Penyediaan

Dana (SPD) yang diterima Pengguna Anggaran dari PPKD selaku BUD, bendahara pengeluaran mengajukan Surat Pengantar Surat Permintaan Pembayaran (SPP) kepada Pengguna Anggaran/Kuasa Pengguna Anggaran melalui Pejabat Penatausahaan Keuangan SKPD. Bendahara Pengeluaran Badan Keuangan Daerah Provinsi Sumatera Barat mengajukan Surat Permintaan Pembayaran (SPP) dalam rangka melaksanakan belanja. Adapun Surat Permintaan Pembayaran (SPP) pada Badan Keuangan Daerah Provinsi Sumatera Barat dikelompokkan menjadi Surat Permintaan Pembayaran Uang Persediaan (SPP-UP), Ganti Uang (SPPGU), Tambah Uang (SPP-TU), dan Langsung (SPP-LS). Untuk mekanisme Belanja Operasi pada Badan Keuangan Daerah Provinsi Sumatera Barat dibagi menjadi :

1. SPP-LS Gaji dan Tunjangan

2. SPP-LS Barang dan Jasa

3. SPP-LS Belanja bunga, belanja subsidi, belanja hibah, dan belanja bantuan sosial

Dalam Peraturan Pemerintah, Surat Permintaan Pembayaran Langsung (SPP-LS) yang diajukan ini harus diverifikasi oleh PPK-SKPD seperti yang diatur dalam Permendagri Nomor 77 Tahun 2020. Proses pengajuan Surat Permintaan pembayaran Langsung (SPPLS) adalah sebagai berikut :

1) Pengguna Anggaran menyerahkan SPD kepada Bendahara Pengeluaran dan PPK-SKPD. Sesuai dengan SPD, maka Bendahara Pengeluaran 
menyiapkan SPP-LS beserta dokumen lainnya yang terdiri dari : (a) Surat Pengantar SPP-LS, (b) Ringkasan SPP-LS, (c) Rincian SPP-LS, (d) Salinan SPD, (e) Surat pernyataan penggunaan anggaran dan (f) Lampiran lain (daftar rincian rencana pengguna dana sampai dengan jenis belanja).

2) Selanjutnya Bendahara Pengeluaran menyerahkan SPP-LS beserta dokumen lain kepada Pejabat Pengelola Keuangan Satuan Kerja Perangkat Daerah (PPK-SKPD).

3) PPK-SKPD meneliti kelengkapan dokumen SPP-LS sesuai dengan SPD dan Dokumen Pelaksanaan Anggaran Satuan Kerja Perangkat Daerah (DPASKPD).

4) SPP-LS yang dinyatakan lengkap akan dibuatkan rancangan Surat Perintah Membayar (SPM) oleh PPK-SKPD. Rancangan SPM ini kemudian diberikan PPK-SKPD kepada Pengguna Anggaran untuk diverifikasi.

5) Apabila SPP-LS tidak lengkap, maka PPK-SKPD akan menerbitkan Surat Penolakan SPM paling lambat 1 hari kerja sejak SPP-LS diterima.

6) Jika SPP-LS sudah diverifikasi oleh Pengguna Anggaran, maka tahap selanjutnya adalah penerbitan Surat Permintaan Pembayaran (SPM) oleh Pejabat Pengguna Anggaran.

Adapun pihak-pihak yang terkait dalam proses penerbitan Surat Permintaan Pembayaran Langsung (SPP-LS) antara lain adalah :

1. Bendahara Pengeluaran

Dalam kegiatan ini Bendahara Pengeluaran mempunyai tugas antara lain :

a) Mempersiapkan dokumen Surat Permintaan Pembayaran Langsung (SPP-LS) beserta lampiran-lampirannya. b) Mengajukan Surat Permintaan Pembayaran Langsung (SPP-LS ) kepada PPK-SKPD.

2. PPK-SKPD atau Pejabat Penatausahaan Keuangan Satuan Kerja Perangkat Daerah

Dalam kegiatan ini PPK-SKPD mempunyai tugas antara lain :

a) Melakukan verifikasi Surat Permintaan Pembayaran Langsung (SPP-LS) beserta bukti kelengkapannya yang diajukan oleh Bendahara Pengeluaran.

b) Menerbitkan surat pernyataan verifikasi kelengkapan dan kebasahan Surat Permintaan Pembayaran Langsung (SPPLS) beserta bukti kelengkapannya sebagai dasar penyiapan SPM.

\section{c) Penerbitan Surat Perintah Membayar (SPM-LS)}

Proses penerbitan Surat Perintah Membayar (SPM) adalah tahapan penting dalam penatausahaan pengeluaran yang merupakan tahapan lanjutan dari proses pengajuan SPP. Sebagai tahapan lanjutan, SPM juga dibedakan menjadi 4 sesuai dengan jenis SPM nya yaitu : (a) SPM Uang Persediaan (SPM-UP), (b) Ganti Uang (SPM-GU), (c) Tambah Uang (SPM-TU), (d) Langsung (SPM-LS).

Dalam hal ini Badan Keuangan Daerah Provinsi Sumatera Barat menerbitkan SPM-LS sejalan dengan ketentuan dalam Permendagri Nomor 77 Tahun 2020, dimana SPM-LS dapat diterbitkan jika pengeluaran yang diminta tidak melebihi pagu anggaran yang tersedia dan didukung dengan kelengkapan dokumen sesuai peraturan perundang-undangan. Sedangkan waktu pelaksanaan penerbitan SPM-LS diterbitkan 
paling lama 2 hari sejak SPP-LS diterima. Apabila ditolak, dikembalikan paling lambat 1 hari sejak SPP-LS diterima.

Adapun proses dalam penerbitan Surat Permintaan Membayar(SPM-LS) pada Badan Keuangan Daerah Provinsi Sumatera Barat adalah sebagai berikut :

1. PPK-SKPD menguji Surat Permintaan Pembayaran Langsung (SPP-LS) beserta kelengkapannya.

2. Setelah SPP-LS dinyatakan lengkap, maka PPK-SKPD membuat rancangan Surat Perintah Membayar (SPM-LS) dan diserahkan ke Pengguna Anggaran untuk diotorisasi.

3. Selanjutnya Pengguna Anggaran menandatangani dokumen SPMLS yang telah diotorisasi.

4. Setelah SPM-LS ditandatangi oleh Pengguna Anggaran, kemudian SPM-LS diajukan kepada Kuasa Bendahara Umum Daerah (BUD) yang akan menerbitkan Surat Perintah Pencairan Dana (SP2D-LS).

Adapun pihak-pihak yang terkait dalam Penerbitan Surat Perintah Membayar (SPM-LS) pada Badan Keuangan Daerah Provinsi Sumatera Barat adalah sebagai berikut :

1. PPK-SKPD

Dalam kegiatan ini PPK-SKPD mempunyai tugas antara lain :

a) Membuat rancangan SPM-LS atas SPP-LS yang telah diuji kelengkapan dan kebenarannya dan mengajukannya ke Pengguna Anggaran.

b) Menyiapakan Surat Perintah Membayar (SPM).

c) Menerbitkan surat penolakan SPM-LS bila SPP-LS yang diajukan oleh Bendahara SKPD tidak lengkap. d) Membubuhkan paraf pada Surat Perintah Membayar (SPM) yang telah dibuatnya.

2. Pengguna Anggaran/ Kuasa Pengguna Anggaran

Dalam kegiatan ini Pengguna Anggaran/Kuasa Pengguna

Anggaran mempunyai tugas antara lain :

a) Mengotorisasi dan menerbitkan SPM-LS

b) Menandatangani SPM-LS

c) Mengotorisasi Surat penolakan SPM-LS yang diterbitkan PPK SKPD bila SPP-LS yang diajukan bendahara SKPD tidak lengkap.

d) Penerbitan Surat Perintah Pencairan Dana (SP2D-LS)

Dalam proses penerbitan SP2D-LS Kuasa BUD mengesahkan dokumen SP2D-LS dengan membubuhkan tanda tangan pada SP2D-LS. Dalam hal ini jika Kuasa BUD berhalangan maka yang bersangkutan dapat menunjuk pejabat yang diberi wewenang untuk menandatangani SP2D-LS tersebut. Surat Perintah Pencairan Dana (SP2D) hanya dibuat untuk satu Surat Perintah Membayar saja. Penerbitan Surat Perintah Pencairan Dana (SP2D) dapat diajukan jika pengeluaran yang diminta tidak melebihi pagu anggaran dan didukung dengan kelengkapan dokumen sesuai peraturan perundangundangan.

Adapun proses dalam penerbitan Surat Perintah Pencairan Dana (SP2D-LS) pada Badan Keuangan Daerah Provinsi Sumatera Barat adalah sebagai berikut :

1. Pengguna Anggaran menyerahkan SPM-LS kepada Kuasa Bendahara Umum Daerah (BUD) lalu Kuasa BUD meneliti kelengkapan SPMLS yang diajukan. Apabila SPMLS dinyatakan lengkap maka Kuasa 
BUD menerbitkan SP2D-LS. Namun apabila dokumen SPM-LS dinyatakan tidak lengkap maka Kuasa BUD menolak untuk menerbitkan SP2D-LS tersebut. SP2D-LS diserahkan kepada Bank dan Pengguna Anggaran.

2. Setelah itu Pengguna Anggaran menyerahkan Surat Perintah Pencairan Dana (SP2D-LS) kepada Bendahara Pengeluaran.

3. Selanjutnya Bendahara Pengeluaran mencairkan dana ke bank atas dasar SP2D-LS beserta dokumen Nota Debit.

Proses penerbitan Surat Perintah Pencairan Dana (SP2D-LS) pada Badan Keuangan Daerah Provinsi Sumatera Barat dilakukan paling lama 2 hari kerja terhitung sejak diterimanya pengajuan SPM-LS oleh Kuasa BUD dan sudah dilaksanakan sesuai dengan Permendagri Nomor 77 Tahun 2020. Dan jika dokumen terkait sudah lengkap maka SP2D-LS juga dapat ditebitkan pada hari yang sama saat diajukan nya SP2D-LS tersebut. Sedangkan penolakan penerbitan SP2D-LS paling lama 1 hari kerja terhitung sejak diterimanya pengajuan SPM-LS. Apabila SP2D-LS ditolak, maka dapat diajukan kembali setelah dilakukan perbaikan dan dilengkapi kekurangan dokumennya.

\section{Adapun pihak-pihak yang terkait dalam Penerbitan Surat Perintah Pencairan Dana (SP2D-LS) antara lain \\ 1. Kuasa BUD \\ Dalam kegiatan ini Kuasa BUD mempunyai tugas antara lain : \\ a) Menerbitkan SP2D-LS \\ b) Menerbitkan surat penolakan SP2D-LS apabila SPM-LS yang diajukan oleh SKPD tidak lengkap.}

2. Bendahara Pengeluaran

Dalam kegiatan ini Bendahara Pengeluaran mempunyai tugas yaitu mencairkan dana ke bank atas dasar SP2D-LS beserta dokumen nota debit.

\section{SIMPULAN}

Berdasarkan hasil penelitian dan analisa dari pembahasan di atas, penulis dapat

menarik kesimpulan yang sekiranya bermanfaat bagi pembaca mengenai Analisis Sistem Penatausahaan Belanja Operasi pada Badan Keuangan Daerah Provinsi Sumatera Barat, yaitu sebagai berikut :

1. Sistem penatausahaan belanja operasi pada Badan Keuangan Daerah Provinsi Sumatera Barat telah dilaksanakan sesuai dengan pedoman yang berlaku yaitu Permendagri Nomor 77 Tahun 2020 tentang Pedoman Teknis Pengelolaan Keuangan Daerah.

2. Dalam sistem penatausahaan belanja operasi terdapat 4 jenis dokumen yang digunakan untuk belanja operasi yaitu : (a) Surat Penyediaan Dana (SPD), (b) Surat Permintaan Pembayaran (SPPUP/GU/TU/LS), (c) Surat Perintah Membayar (SPM-UP/GU/TU/LS), dan (d) Surat Perintah Pencairan Dana (SP2D).

3. Sistem penatausahaan belanja operasi pada Badan Keuangan Daerah Provinsi Sumatera Barat dapat kita simpulkan bahwa belanja operasi merupakan pengeluaran anggaran untuk kegiatan sehari-hari Pemerintah Daerah yang memberi manfaat lebih dari 1 (satu) periode akuntansi. Belanja operasi terbagi atas beberapa jenis diantaranya : (a) Belanja pegawai, (b) Belanja barang dan jasa, (c) Belanja bunga, subsidi, hibah, dan bantuan sosial.

4. Pada sistem penatausahaan belanja operasi di Badan Keuangan Daerah Provinsi Sumatera Barat dimulai dari Penerbitan Surat Penyediaan Dana 
(SPD) yang diterbitkan oleh Pejabat Pengelola Keuangan Daerah (PPKD) setelah itu Bendahara Pengeluaran mengajukan Surat Permintaan Pembayaran (SPP-LS) kepada Pengguna Anggaran/Kuasa Pengguna Anggaran melalui Pejabat Pengelola Keuangan Satuan Kerja Perangkat Daerah (PPK-SKPD). Apablia SPPLS yang sudah diverifikasi oleh Pengguna Anggaran, maka tahap selanjutnya adalah penerbitan Surat Permintaan Pembayaran (SPM) oleh Pejabat Pengguna Anggaran. Selanjutnya Pengguna Anggaran menandatangani dokumen SPM-LS yang telah diotorisasi. Setelah SPMLS ditandatangi oleh Pengguna Anggaran, kemudian SPM-LS diajukan kepada Kuasa Bendahara Umum Daerah (BUD) yang akan menerbitkan Surat Perintah Pencairan Dana (SP2D-LS).

Berdasarkan kesimpulan yang telah diuraikan sebelumnya, penulis mengajukan beberapa saran sebagai berikut :

1. Dalam kegiatan penatausahaan belanja operasi pada bendahara pengeluaran sebaiknya tetap dalam tahap taat sehingga Badan Keuangan Daerah Provinsi Sumatera Barat dapat menjadi teladan bagi satuan kerja perangkat daerah lain dalam menjalankan tugasnya.

2. Tetap menjaga komunikasi yang baik dengan pejabat-pejabat pelaksana penatausahaan keuangan daerah di Badan Keuangan Daerah Provinsi Sumatera Barat agar tidak terjadi kesalahan sehingga sistem penatausahaan pada instansi atau divisi dapat berjalan dengan baik.

\section{DAFTAR PUSTAKA}

Afifuddin. 2009. Metodologi Penelitian Kualitatif. Bandung: CV Pustaka Setia

Halim, Abdul dan Muhammad Syam Kusufi.2013, Akuntansi Sektor Publik, Akuntansi Keuangan Daerah.Jakarta : Salemba Empat.

Kuncoro, Mudrajad.2007. Metode Kuantitatif: Teori dan Aplikasi Untuk Bisnis dan Ekonomi. Yogyakarta: UPP STIM YKPN.

Mahsun, dkk. 2016. Akuntansi Sektor Publik. Edisi Ketiga.Yogyakarta : BPFE

Martani, Dwi, dkk. 2012. Akuntansi Keuangan Menengah Berbasis PSAK. Buku Satu. Jakarta : Salemba Empat.

Muhammad, Nasir. 1999. Metode Penelitian. Jakarta : PT Ghalia Indonesia.

Nikita, dkk. 2016. Sistem dan Prosedur Akuntansi Belanja Langsung pada Kantor Pelayanan Perijinan Terpadu Provinsi Sulawesi Utara. Volume 16 No.04 Jurnal Berkala Ilmiah Efisiensi. Nordiawan, Deddi, dkk. 2012. Akuntansi Pemerintahan. Jakarta : Salemba Empat.

Rasdianto, Erlina. 2013. Akuntansi Keuangan Daerah Berbasis Akrual.Medan : Brama Ardian.

Sugiyono. 2003. "Metode Penelitian Bisnis". CV Alfabeta, Bandung.

Singgima, Febrian dan Sherly Pinatik.2016. Evaluasi Prosedur Pengeluaran Kas Belanja Langsung pada Dinas Pendidikan Provinsi Sulawesi Utara. Vol. 4 No. 1.

Pandoh, Fiolita Gabriella. 2016. Evaluasi Sistem Pencatatan Belanja Langsung Pada Dinas Pekerjaan Umum Kabupaten Minahasa Tenggara. Jurnal EMBA. Vol. 4 No. 1 Maret 2016, Hal.1097-1106. 
Parayanti, Eni. 2015. Evaluasi Sistem dan prosedur Akuntansi Belanja Pada Satuan Kerja Perangkat Daerah Dinas Kesehatan Provinsi Sulawesi Utara. Jurnal EMBA. Vol. 3.No. 3 Sept. 2015, Hal.608-618.

Wonggo, Putri Marina, dkk. 2017. Analisis Sistem Penatausahaan Belanja Langsung di Pemerintah Kabupaten Minahasa Selatan (Studi Kasus pada Dinas Sosial, Tenaga Kerja dan Transmigrasi).Jurnal Riset Akuntansi Going Concern 12(2).

Republik Indonesia. 2004. UndangUndang No 33 Tahun 2004 Tentang Perimbangan Keuangan antara Pemerintah Pusat dan Pemerintah Daerah. Jakarta.

Republik Indonesia. 2019. Peraturan Menteri Nomor 12. Tahun 2019. Tentang Pengelolaan Keuangan Daerah. Jakarta.

Republik Indonesia. 2020. Peraturan Menteri Dalam Negeri Nomor 77. 2020. Tentang Pedoman Teknis Pengelolaan Keuangan Daerah Tahun. Jakarta.

Republik Indonesia. 2010. Peraturan Pemerintah Nomor 71. 2010. Tentang Standar Akuntansi Pemerintahan. Jakarta.

Tanjung, A.H. 2012. Akuntansi Pemerintah Daerah Berbasis Akrual : Pendekatan Teknis Sesuai dengan PP No. 71/2010. Bandung Alfabeta.

Weygandt, Kimmel \& Kieso. 2018. Pengantar Akuntansi Berbasis IFRS. Edisi Dua. Jakarta : Salemba Empat. 